\title{
Evaluation of the Efficacy of Plant Powders, Cow Dung Ash and Malathion Dust against Callosobruchus Chinensis L. (Coleoptera: Bruchidae) On Chickpea in Jole Andegna: Southern Ethiopia
}

\author{
Kebebush Tesema \\ Hawassa University, College of Agriculture, School Nutrition \\ Food Science and Technology P.O.Box 05, Hawassa, Ethiopia \\ E-mail: kebebush04@gmail.com
}

\begin{abstract}
Henok Kurabachew (Corresponding author)
Hawassa University, College of Agriculture, School of Nutrition Food Science and Technology P.O.Box 05, Hawassa, Ethiopia E-mail: henok.k5@gmail.com
\end{abstract}

Teferra F. Tadesse

Hawassa University, College of Agriculture, School Nutrition

Food Science and Technology P.O.Box 05, Hawassa, Ethiopia

E-mail: tadessefikre@gmail.com

Received: February 17, 2015 Accepted: March 2, 2015

doi:10.5296/jas.v3i2.7775 URL: http://dx.doi.org/10.5296/jas.v3i2.7775

\begin{abstract}
Callosobruchus chinensis is one of the major insect pest of chickpea and other stored legume which is known to cause significant yield loss both quantitatively and qualitatively. This investigation was done to study the efficacy of leaf powders of basil (Ocimu basilica L.) and neem (Azadirachta indica), cow dung ash and Malathion dust against bruchid on two chickpea varieties namely Desi (local) and Habru (improved Kabuli). Levels of infestation,
\end{abstract}


weight loss, germination capacity (delete) and germination of the seeds were evaluated monthly up to six months. In the bruchid infested treatment (control), hundred seeds weight, seed germination decreased through time while levels of infestation and weight loss increased. All the tested locally available treatments (cow dung ash, leaf powder of neem and leaf powder of basil) were found to be effective in reducing the damage inflicted by bruchid compared to the control. Malathion dust was observed to be the most effective of all treatment in this study. However, looking in to the side effects of synthetic pesticides, we suggest that the locally available plant powders and cow dung ash which is cheap, ecologically friendly and non-hazardous to human health can play an important role in protection of chickpea during storage against invasion by bruchid.

Keywords: Azadirachta indica, Ocimu basilica, bruchid, chickpea, Malathion dust.(delete)

\section{Introduction}

Chickpea (Cicer arietinum L.) is a highly nutritious pulse cultivated throughout the world and is placed third in the importance list of the food legumes. Ethiopia is the largest producer of chickpea in Africa accounting for about $46 \%$ of the continent's production. It is also the seventh largest producer worldwide and contributes about $2 \%$ to the total world chickpea production (FAOSTAT, 2008). Chickpea, locally known as shimbra, is one of the major pulse crops in Ethiopia and it is the second most important legume crop after faba bean. It contributed about $16 \%$ of the total pulse production during 1999-2008. The total annual average (1999-2008) chickpea production was estimated to be about 173 thousand tones. During the same period, chickpea was third after faba beans and field peas in terms of area coverage (Menale et al., 2009).

Pulses are invariably infested with beetle and weevil in fields as well as during storage time (Adugna, 2006). Callosobruchus chinensis L. is one of the most destructive pests of chickpea in storage (Aslam, 2004). The pest not only inflicts qualitative and quantitative losses, but also damage their germinating capacity, and nutritional value which make the grains unfit for human consumption as well (Atwal and Dhaliwal, 2005; Righi-Assia et al.,2010). Losses as high as $50 \%$ often encountered in some of the important legumes such as faba bean, field pea, chickpea and lentil from some belligerent storage insect pests like $C$. chinensis (Ali and Habtewold, 1993; Damte and Dawd, 2006). Even with only a small amount of actual biological losses, economic losses can reach up to 100\% (Boeke et al.; 2004; Somta et al., 2006). Despite the importance of storing seeds as a strategy of stabilizing market prices associated with the balance between supply and demand (CIAT, 1986), the damages often wreaked by the pests, particularly under small-scale farmers' conditions obstruct optimal use of the market opportunities (Damte and Dawd, 2006). Traders, food processors, and finally consumers also suffer from the loss due to storage pest damage.

Synthetic insecticides play a significant role in reducing storage losses due to insect pests (Tapondjou et al., 2002). However, the persistent use of these insecticides in granaries of small- scale farmers has led to a number of problems such as killing non-target species, pose risk to human health, toxic residues in food, development of genetic resistance,,(delete) increased cost of application and destruction of the balance of the ecosystem (Shaheen and 
Khaliq, 2005; Boateng and Kusi, 2008). Plant products have been used for many years by the small scale farmers in parts of Africa to protect stored products from insect infestation (Bekele, 2002; Tapondjou et al., 2002). In this regard many efforts have been made to screen plants with better botanical insecticides which can be used as an alternative to synthetic insecticide (Emana et al., 2003). Thus this investigation was carried out to evaluate the efficacy of locally available botanical plant powders and cow dung ash at Jole Andega province (Southern Ethiopia) for controlling C. chinensis.

\section{Materials and Methods}

\subsection{Survey of the Chickpea Storage Practices and Problems}

A survey was conducted at Meskan Woreda, Jole Andegna Kebele having $10^{\circ} \mathrm{C}$ to $17^{\circ} \mathrm{C}$ annual mean temperature, 1001 to $1200 \mathrm{~mm}$ annual rainfall, and red (22\%), black (53\%) and grayish $(25 \%)$ soil type. The area has high potential for chickpea production but heavily suffers from the damage by bruchid during storage.

Purposive sampling technique was used to select target group of farmers who have been cultivating and storing one of the chickpea varieties under the study for at least a year. The survey was administered for 86 farmers with ample experience and knowledge about storing, managing and identification of the causes of postharvest losses of chickpea.

\subsection{Storage Experiment}

\subsubsection{Sample Seed Preparation and Insect Rearing}

Chick pea seeds varieties (Harbu and local) bought from local market in Meskan were cleaned and kept in refrigerator for four weeks to avoid any latent insect infestation before treatment application (IIeke et al., 2013). Insect rearing was carried out in farmer's home at Jole Andegna Kebele in ambient condition. Chickpea seeds infested with bruchids ( $C$. chinensis) were mixed with the healthy one and were kept in plastic jars, which were covered by muslin cloth, for one month.

\subsubsection{Plant Extracts, Dung Ash and Chemical Insecticides}

Fresh green leaves of neem (Azadirachta indica) and basil leaf (Ocimu basilica) were collected and kept in the laboratory for 7 days for air drying followed by one day sun drying before making powder. Dried leaves were milled using electric grinder and sieved through 60-mesh sieve to get the finest powder. Similarly, dried cow dung was collected from farmers' home at Jole Andegna Keble and burned on clean sheet metal and then the ash was sieved via $710 \mu \mathrm{m}$ mesh size to get the finest dust. Storage treatment was applied according to recommendations set by Organic Organization HDRA (1998), Shaheen and Khaliq (2005) and Ahmed and Din (2009) where: $100 \mathrm{~g}$ of neem leaf powder, $200 \mathrm{~g}$ of basil leaf powder and $100 \mathrm{~g}$ of cow dung ash were applied respectively to $5 \mathrm{~kg}$ of chickpea samples. Malathion dust of $3.75 \mathrm{~g}$ was applied to the same amount of sample.

The $5 \mathrm{~kg}$ chickpea seed samples were filled in polyethylene bags in triplicate. All treatments were maintained under ambient conditions for 6 months at Butajira Horticulture Research 


\section{Macrothink}

Centre. All bags were loaded on pallets that were made from wood slabs. The polyethylene bags were kept in round orientation keeping the infested chickpea seed bag at the centre and while the remaining treatments were kept at equal distance from the infested treatment. The experiment was laid down in completely randomized design (CRD) with five treatments and three replications.

\section{List of treatments in the experiment}

T1. Chick pea treated with cow dung ash and infested with bruchid

T2. Chick pea treated with neem leaf powder and infested with bruchid

T3. Chick pea treated with basil leaf seed powder and infested with bruchid

T4. Chick pea treated with Malathion dust and infested with bruchid

T5. Chick pea with no treatment and infested with bruchid (control)

\subsubsection{Percent of Infestation}

For determination of percent infection, 100 seeds were drawn randomly from each treatment and investigated manually. Seeds with holes, egg spot or both were counted as infested seeds and the percentage of infestation were calculated as follow:

$\% \mathrm{I}=\left(\frac{\mathrm{Nh}}{\mathrm{No}}\right) \times 100$

Where: $\% \mathrm{I}=$ percent of infestation, $\mathrm{Nh}=$ number of seeds with emergent holes \&

$\mathrm{No}=$ total number of seeds observed

\subsubsection{Weight Loss}

The weight loss of chickpea seed caused by $C$. chinensis was measured every month throughout the experiment according to the method of Farid and Abdul (2005) using the following formula:. (delete)

Weigh $\operatorname{loss}(\%)=\left(\frac{A-B}{A}\right) \times 100$

Where $\mathrm{A}=$ initial weight at initial storage time

$\mathrm{B}=$ weight of grains at sample taking time

\subsubsection{Seed Size and Hundreds (delete) Seeds (delete) Weight}

The seed size was measured simply using a digital calliper before and after storage. Thirty randomly selected seeds were used to measure length, width and thickness using the digital calliper and mean values were calculated. Hundred seed weight was determined according to the AACC method 56-35.01. Broken and damaged seeds along with foreign materials were 
handpicked from the sample. One hundred seeds were counted using a custom-made seed sampling paddle and weighed.

\subsection{Seed Germination}

For germination test, one hundred seeds of chickpea from each treatment and variety were placed on moistened soft paper on flat dish and kept at room temperature. Germinated seeds were recorded and the remaining samples were watered daily for ten days. Speed of germination was calculated by using formula:

$\mathrm{SG}=\frac{\mathrm{N} 1+\mathrm{N} 2+\mathrm{N} 3+\cdots+\mathrm{Nn}}{\mathrm{D} 1+\mathrm{D} 2+\mathrm{D} 3+\cdots+\mathrm{Dn}}$

Where: $\mathrm{SG}=$ Speed at germination

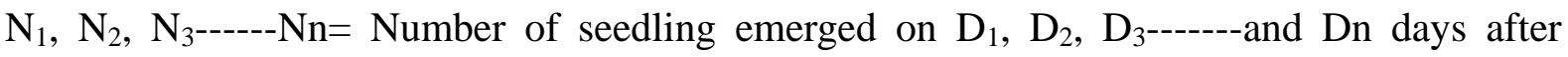
sowing, respectively

\subsection{Data Analysis}

The Statistical Analysis System program (SAS version 9.0) was used for analysis of variance (ANOVA). Mean values were separated using the Fischer's least significant differences (LSD) procedures. Significance levels were given for $\mathrm{P}<0.05$.

\section{Results and Discussion}

\subsection{Survey on Chickpea Production and Storage Practices in Jole Andegna Kebele}

The survey result indicated that only one farmer completely allocate the farm for chickpea production and about 52 farmers $(60.5 \%)$ cultivate the crop using one fourth of their land (Table 1). This clearly indicated that the crop is not very popular in the area comparing to other crops. In most cases they produced chickpea for home consumption and partly for sale and some cultivated the crop for seeds to the next season which serve as a good source of income.

Table 1. Land size allocation for chickpea production in Jole Andegna Kebele

\begin{tabular}{|l|l|l|}
\hline Land size allocated for chickpea production & No. of Farmers & Percent $(\%)$ \\
\hline $1 / 4^{\text {th }}$ of the total land & 52 & 60.5 \\
\hline $1 / 2^{\text {th }}$ of the total land & 26 & 30.2 \\
\hline $3 / 4^{\text {th }}$ of the total land & 2 & 2.3 \\
\hline The whole land & 1 & 1.2 \\
\hline $1 / 3^{\text {th }}$ of the total land & 5 & 5.8 \\
\hline
\end{tabular}

It was found that only one farmer used (delete) leaf powder of China berry (Melia Azdarach) for chickpea storage while the rest of the farmers used the synthetic chemical insecticides Malathion dust (MD) to minimize the damage inflicted by bruchid during storage of the grains (Table 2). 


\section{Macrothink}

Table 2. Common chickpea storage methods in Jole Andegna Kebele

\begin{tabular}{|l|l|l|}
\hline Methods used for chickpea storage & Frequency & Percent (\%) \\
\hline Sundry & 1 & 1.2 \\
\hline Chemical treatment & 74 & 86 \\
\hline Locally available plant & 1 & 1.2 \\
\hline Sundry and Chemical treatment & 4 & 4.7 \\
\hline Chemicals and Locally available plant & 2 & 2.3 \\
\hline Cold place & 2 & 2.3 \\
\hline Other & 1 & 1.2 \\
\hline Nothing & 1 & 1.2 \\
\hline
\end{tabular}

The local farmers dislike the odour of Malathion dust and fear that it may cause breathing system complications on the person who applies it. In this regard, the chemical insecticides residual toxicity, environmental hazards and pest resistance of made botanical extracts a prime alternative choice again. In this regard DARP (2003) reported that Malathion resistance developed by the bruchid pest was found all over the world and currently about 122 insect-pest species have been found to be resistant to this insecticide. Therefore, utilization of locally available storage methods is economical and healthy for the resource poor farmers.

\subsection{Storage Experiment}

\subsubsection{Percent Seed Infestation and Weight Loss}

Clear difference in percentage of infestation was observed between the two chickpea varieties during storage experiments (Figure 1). The result indicated that the control sample of desi (local variety) was highly susceptible to $C$. chinesis $(55 \%)$ than that of the control sample of Habru $(20 \%)$ at the end of six months of storage. The different storage treatments decreased the infestation of chickpea by $C$. chinesis compared to control (untreated chickpea seeds). In the local variety, cow dung ash minimized infestation of seeds with $C$. chinesis which had only average $0.83 \%$ infested followed by leaf powder of neem $1.17 \%$ and leaf powder of basil $4.50 \%$ in six months of storage. In Harbu variety, leaf powder of basil was the best in reducing infestation $1.17 \%$ followed by leaf powder of neem $2.33 \%$ and cow dung ash $3.33 \%$. However, Malathion dust gave least infestation in both desi and harbu type samples. 

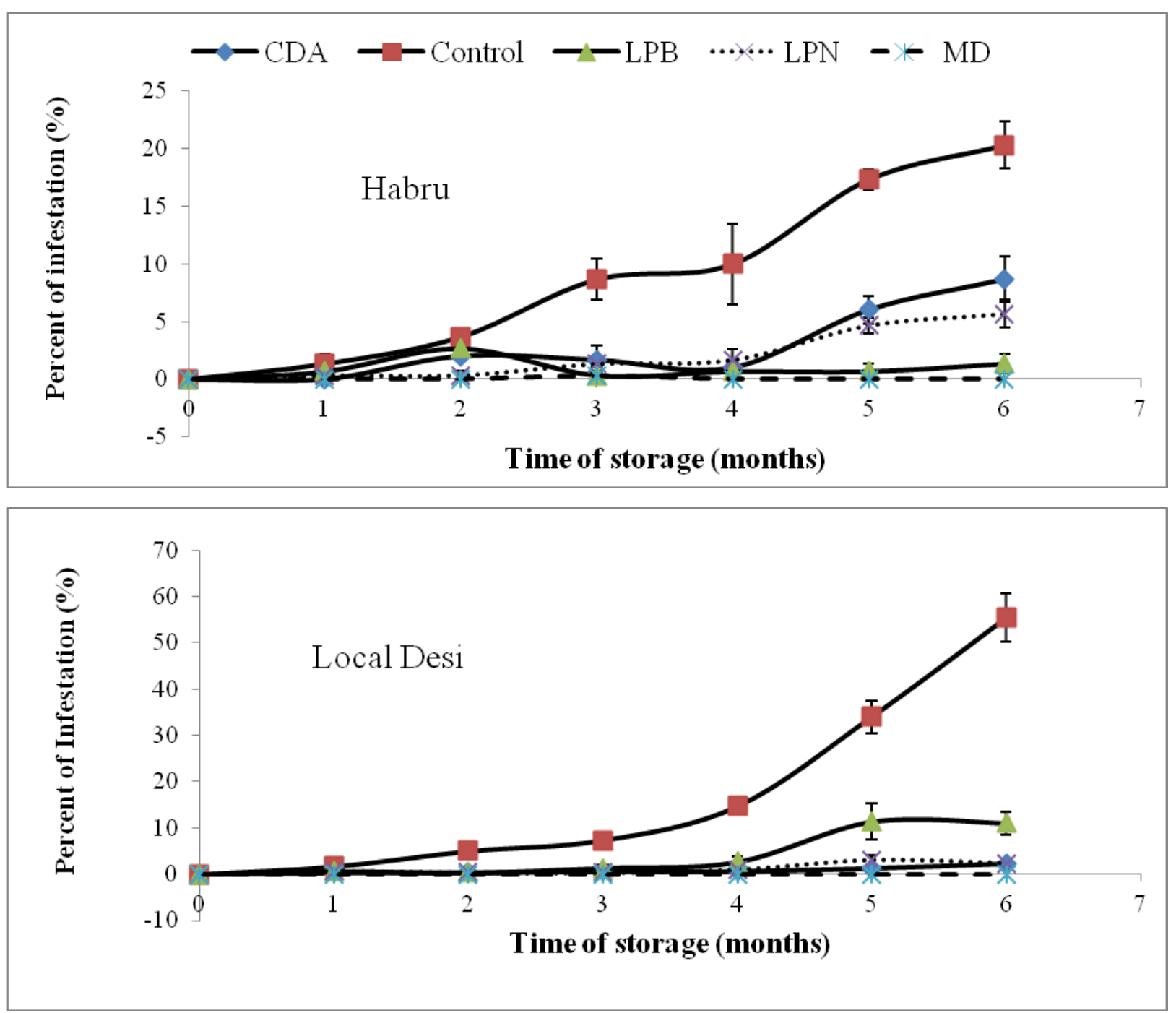

Figure 1. Effects of storage treatments on percent of infestation of chickpea

The result indicated that all storage treatments had considerable effect on reduction of weight compared to the control. The least loss was recorded for sample treated with Malathion dust (MD) which was $0.25 \%$ and $0.5 \%$ on Habru and Local varieties of chickpea, respectively. Among the locally available treatments cow dung ash (CDA) reduced the weight loss by $3.78 \%$ in Habru and $3.98 \%$ in Local varieties followed by of leaf powder of basil by $8.3 \%$ and $8 \%$ and leaf powder of neem by $7.43 \%$ and $8.6 \%$ in Habru and Local, respectively (Figure 2). 


\section{Macrothink}
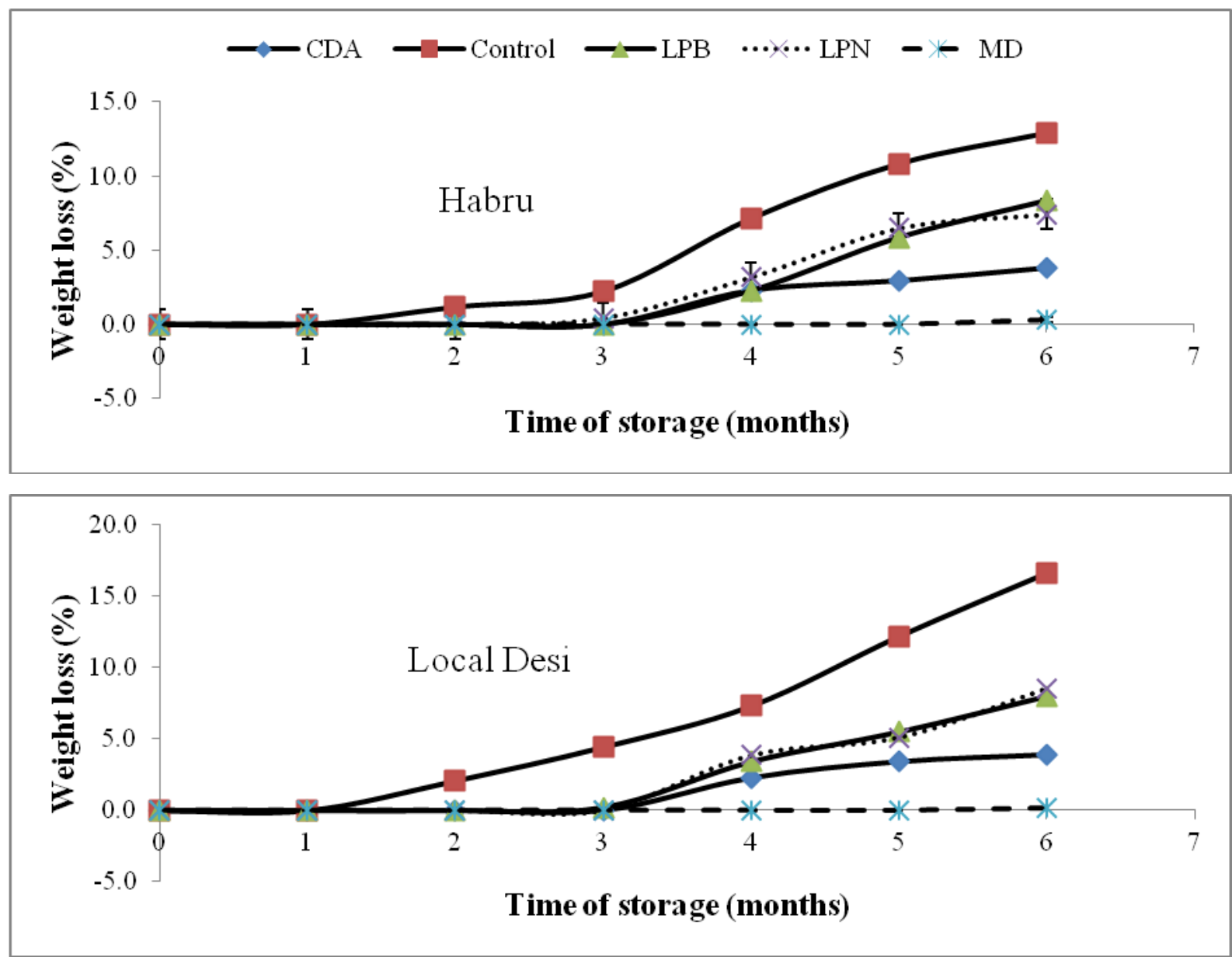

Figure 2. Effects of storage treatments on weight loss of chickpea

The findings of the present investigation showed that the repellent and deterrent effects of the leaf powders of neem and basil agianst C.chinensis was a promising alternative to Malathion dust. The repellent and deterrent effects of leaf powder of basil and neem was different on the survival and emergence of $C$. chinensis indicating the pest controlling factors are not uniformly present in every aromatic plant. The leaf powder of neem showed better activity against bruchid than leaf powder of basil. The reduction in percent infestation in this experiment could be explained either as egg mortality or larval mortality. It has been reported that the larvae which hatch from the eggs of Callosobruchus species must penetrate the seeds to survive (FAO, 1999). The larvae are unable to do so unless the eggs are firmly attached to the seed surface. In the present study, the eggs were found to be loosely attached to the chick pea seed surface in the treated sets of treatments. The leaf powders of basil and neem might thus have inhibited the larval penetration into the seed and thus showed reduced levels of seed infestation and weight loss.

The growth inhibitory or insecticidal effect of plant powders may attribute to one or more such properties as stomach poisoning effect where insects feed on admixed grains and pickup lethal doses of treatment particles and these particles might reduce insect movement and also cause death through occlusion of their spiracles, thereby preventing respiration via trachea (Shaheen and Khaliq, 2005). In this regard the characteristic garlicky odour of neem 
materials presumably repelled the bruchid and the bitter components present in neem deterred feeding. Furthermore, different researches have revealed that the neem materials whether raw, enriched, or purified affect insect pest behaviour, growth and development, and survival and reproduction.. (delete) (Pascual et al., 1990; Saxena et al., 1989; Singh, 1993). The findings of the present investigation is in accordance with that of other researchers who have previously reported the effectiveness of Lantana camara (Koona and Njoya, 2004), Murraya koenigii and Eupatorium cannabinum (Shukla et al., 2007) and Neem (Hasan et al., 2012, Tabu et al., 2012) against $C$. chinensis. Dried powders of clove, red and black pepper have also been reported to prevent the infestation of legume by bruchids at a dose of $25 \mathrm{~g} / \mathrm{kg}$ (Aslam, et al., 2002). In the current experiment chickpea seed damage is not $100 \%$ reduced by neem or basil leaf powders. However, the use of the plant powders has a significant economic advantage and service to rural areas in tropical developing countries if reliable recommendations can be made and given to farmers for the protection of stored commodities.

Similarly, cow dung ash can offer an effective way to protect stored seeds against storage beetles, if it is applied in large quantities. The effect of the ash is caused by a mechanical rather than by a chemical action. The ash hinders adult movement and thus hampers oviposition (Boeke et al., 2003). The applied ash does not only hamper beetle movement, but it can also do physical damage to the adult beetles. If the adult insects move over or through the ash, their bodies (De Groot, 1991), especially the layer of chitin on the adults' abdomen are grazed. This result in clogging of insect spiracles and tracheae (Wolfson et al., 1991) or blocking of the lateral stigmates, all essential for respiration, cause suffocation of the adult and enhance mortality (De Groot, 1997). The result of the current investigation also comply with that of (Hampanna et al., 2006) who reported that cow dung ash (2.0\%) and dry cow dung powder $(20.0 \%)$ were effective in reducing weight loss, seed damage and population build up of rice weevil and pulse beetle. Sudheer Reddy et al. (1993) also reported that addition of cow dung ash at $200 \mathrm{~g} / \mathrm{kg}$ seeds to be effective without grain damage by Rhizopertha dominica after storage period of six months.

\subsubsection{Seed Size and Hundred Seeds Weight}

Habru variety (Kabuli type) chickpea had larger seed size $(7.13$ to $7.50 \mathrm{~mm})$ than that of the local desi variety $(5.59$ and $5.99 \mathrm{~mm})$. The time of storage and storage treatments did not affect the seed size of both chickpea varities.

Hundred seed weight decreased for both varieties after the six months storage period (Figure 3 ). The hundred seeds (delete) weight of Habru variety decrease from $26.6 \mathrm{~g}$ to $24.6 \mathrm{~g}$. The seed weight of the local variety decreased from $12.47 \mathrm{~g}$ to $11.17 \mathrm{~g}$. All the seed treatments gave some degree of protection against seed weight loss. In this regard Malathion dust was the most effective followed by cow dung ash. Leaf powder of neem better maintained seed weight the local variety chick pea than the leaf powder of basil. Neem leaf powder was more effective in maintaining the seed weight for the Habru variety. 


\section{Macrothink}
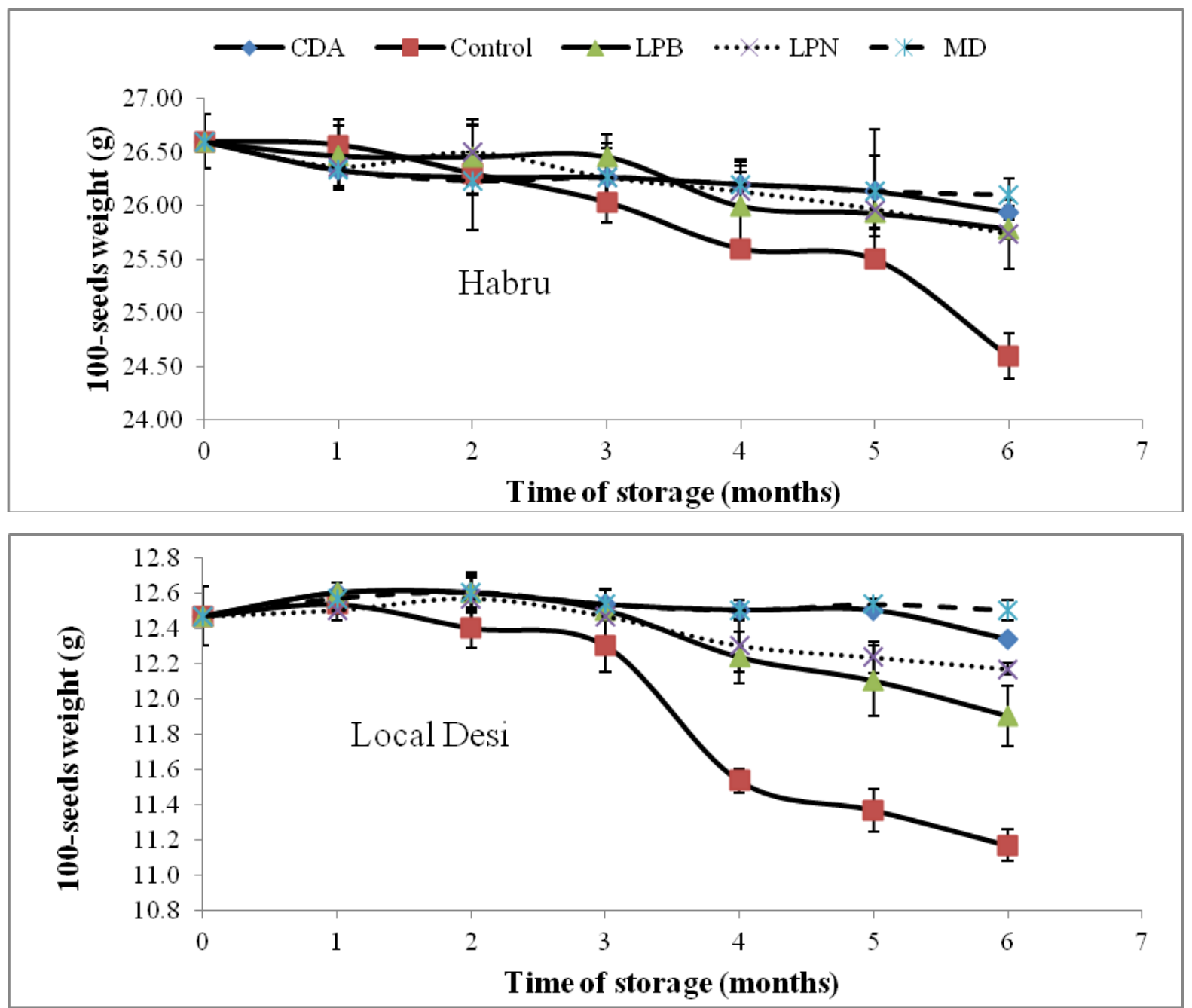

Figure 3. Effects of storage treatments on hundred seeds weight of chickpea.

The seed size and weight (100-seeds weight) depend one on each other. The local Desi type chickpea had a smaller seed size and 100-seeds size than the improved Kabuli type of Habru chickpea. This was supported by the results of study by Hossain et al. (2010). There was no change on seed size during the six months storage due to the different storage treatments. Seed size is an important attribute that determines the consumer preference and cooking quality of chickpea cultivars (Malik et al., 2011) and it is one of the factors which determine the storability of seeds. The morphology of the seed such as size, uniformity of size and seed shape are varietals character that are key factors affecting the de-hulling process of pulses (Reichert et al., 1984). These properties play a vital role in the selection of sieves and de-hulling machines. In the current investigation, the different treatments had no significant effect on chickpea seed size in both varieties over the six months of storage experiment which is in agreement with the results of Hossain et al. (2010). Hundred seeds(delete) weight of the chickpea seeds in both varieties decreased in the control treatment due to damage inflicted by $C$. chinensis during storage experiment. However, all treatments managed to reduce the damage compared to the control. 


\section{$\triangle$ Macrothink}

\subsubsection{Seed Germination}

The chickpea seed sample stored without any protection against bruchids (control) reduced the germination performance of the seeds (Figure 4). The germination of seeds of Habru declined from 1.81 to 1.68 seeds day $^{-1}$ and the Local variety from 1.82 to 1.75 seeds day ${ }^{-1}$ after six months of storage. The storage treatments maintained germination capacity of the seeds compared to the control. The sixth month of result of speed of germination were 1.79, 1.78, 1.76 and 1.68 seeds day $^{-1}$ for the Habru samples treated with leaf powder of basil, Malathion dust, both cow dung of ash and leaf powder of neem and the control, respectively. The speed of germination of local variety sample were 1.81, 1.80, 1.79 and 1.75 seeds day $^{-1}$ due to treatments of Malathion dust, cow dung ash and leaf powder of neem, leaf powder of basil and control sample at the end of six months of storage.
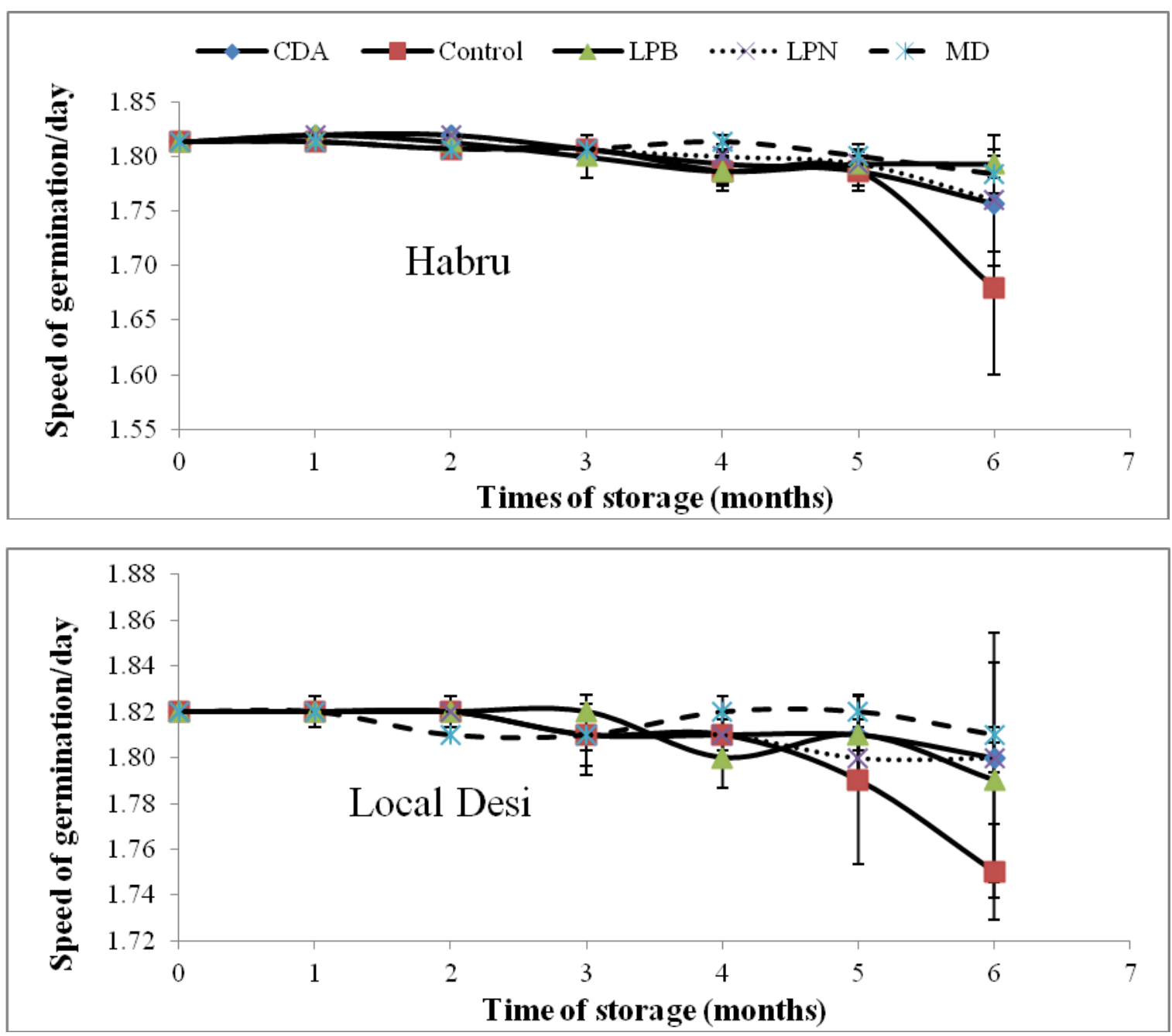

Figure 4. Effects of storage treatments the rate of seed germination of chickpea

The result of germination of chickpea seed (Fig 4) showed that the germination of chickpea grain declined with the increase of storage time. Germination rate in the treated seeds was significantly higher. The treated chickpea seeds in both varieties showed higher germination performance compared to the control. This result indicated the bruchid attack altered the 
germination of the control samples. It also showed that the powders of plant leaves, cow dung ash and the synthetic insecticides did not show any adverse effect on the germination capacity of chickpea seeds. Kasa and Tadesse (1995) investigated the use of crude powders from 17 plants for the control of $S$. zeamais on sorghum and reported that the plants had no effect on seed germination. Similarly, Keita et al. (2001) and Araya and Emana (2009) reported that powders of $O$. basilica ; J. curcas , D. stramonium, C. ambrosioides, P dodecondra, A. indica and $P$. hysterophorus provided complete protection against $C$. maculatus and $\mathrm{Z}$. subfasciatus, respectively and also did not show significant effect on seed germination.

\section{Conclusion}

The current investigation demonstrated that the tested botanicals and cow dung ash possesses insecticidal properties that can be used for the control of $C$. chinensis in stored chickpea. The availability of these botanical plant powders and cow dung ash in the farm yard of most of the chickpea grower is another additional value which made these methods of storage preferred than other methods of control like chemical of insecticides. Thus, the result of this study showed that the locally available treatments gave good protection the damage inflicted by bruchid on chickpea grains during storage. Therefore, much effort should be done for the success and sustainability of this inexpensive, healthy, easily available and ecological friendly pest control method for the small-scale and resource poor farmers.

\section{Acknowledgements}

The authors would like to thank the Canadian International Food Security Research Fund (CIFSRF) for the financial support. The authors also appreciate Butajira Horticultural Research Centre for provision and facilitation of storage space.

\section{References}

Adugna, H. (2006). On farm storages studies in Eritrea. African Journal of Biotechnology, $5(17), 1537-1544$.

Ahmed, S., \& Din, N. (2009). Leaf Powders of basil (Ocimum Basilicum L.), Lantana (Lantana Camara L.) and Garenia (Gardenia Jasminoides Ellis) Affect Biology of Callosobruchus Chinensis L. (Coleoptera: Bruchidae). Journal of. Pakistan Entomology, 31(1), 5-8.

Araya, G. S., \& Emana, G. (2009). Evaluation of botanical plants powders against Zabrotes subfasciatus (Boheman) (Coleoptera: Bruchidae) in stored haricot beans under laboratory condition. African Journal of Agricultural Research. 4, 1073-1079.

Aslam, M. (2004). Pest status of stored chickpea beetle Callosobruchus chinensis L. on chickpea. Journal of Entomology, 1(1), 28-33. http://dx.doi.org/10.3923/je.2004.28.33

Atwal, A. S., \& Dhaliwal, G. S. (2005). Agricultural pests of South Asia and their management. $5^{\text {th }}$ edition. Kalyani publishers, New Delhi, India p 390. 
Bekele, J. (2002). Evaluation of the toxicity potential of Milletia ferruginea (Hochest) Baker against Sitophilus zeamais Mots. International Journal of Pest Management, 42(1), 29-32. http://dx.doi.org/10.1080/09670870110065253

Boateng, B., \& Kusi, F. (2008). Toxicity of Jatropha Seed Oil to Callosobruchus maculatus (Coleoptera: Bruchidae) and its Parasitoid, Dinarmus basali (Hymenoptera: Pteromalidae). Journal of Applied Science Research, 4, 945-951.

Boeke. S. J., Baumgarta, I.R., Jvan Loona, J.A., van Huisa, A., Dickea, M., \& Kossoub, D.K. (2004). Toxicity and repellence of African plants traditionally used for the protection of stored cowpea against Callosobruchus maculatus. Journal of Stored Product Research, 40, 423-438. http://dx.doi.org/10.1016/S0022-474X(03)00046-8

Boeke, S. J., Antonia, A. C., Rauls, W. M., Gilsang, P. J., Dansai, K. K., \& Jrop, J. A. (2003). Side effects of cowpea treatment with botanical insecticides on two parasitoiuds of Callosobruchus maculatus. Entomologia Experimentalis at Applicata, 108, 43-51. http://dx.doi.org/10.1046/j.1570-7458.2003.00066.x

CIAT (Centro Internacional de Agricultura Tropical). (1986). Main Insect Pests of Stored Beans and Their Control: A Study Guide, Series 04EB-05.03, Apartado Aéreo 6713; CIAT (Centro Internacional de Agricultura Tropical): Cali, Colombia.

Damte, T., \& Dawd, M. (2006). Cickpea, lentil and grass pea insect pest research in Ethiopia: A review. In: Ali K, Keneni G, Ahmed S, Malhotra R, Beniwal S, Makkouk K, Halila MH, editors. Food and Forage Legumes of Ethiopia: Progress and Prospects, Proceedings of a Workshop on Food and Forage Legumes, Addis Ababa, Ethiopia, 22-26 September 2003; ICARDA: Aleppo, Syria. pp. 260-273.

DARP. (2003). Data base of Arthropods Resistant to Pesticides. Resistant Management at Michigan State University. Available at http://www.pestcideresistance.org/DB/.

De Groot, U. M. (1991). Protection of stored grains and pulses. Agrodok 18, Agromisa, Wageningen, The Netherlands, $45 \mathrm{pp}$.

De Groot, U. M. (1997). Niébé techniques de controle intégré des problèmes phytosanitaires. (CIPP) Volet Recherche et Développement Activité 33272. 14 pp.

Emana, G., Ahmed, I., \& Fridissa, I. (2003). Review of lowland pulse insect pest research in Ethiopia. Proceedings of grain legume workshop, 22-27 September, 2003, Addis Ababa, Ethiopia.

FAO. (1999). Botanical oils as grain protectants, In: The use of spices and medicinals as bioactive protectants for grains. FAO Agricultural Services Bulletin No. 137. FAO,Vialle delle Terme di Caracalla, 00100 Rome, Italy.

Farid, A. S., \& Abdu, 1. K. (2005). Management of Pulse Beetle, Callosobruchus chinensis L. (Coleoptera: Bruchidae) in Stored Chickpea using Ashes, Red Soil Powder and Turpentine Oil. Department of Entomology, University of Arid Agriculture, Rawalpindi. Ref.Pak. Entomol. Vol. 27, No.2, 2005. 
Hampanna, A.Y.L., Naganagoud, \& Patil, B.V. (2006). Evaluation of Animal Origin Inert Materials against Rice Weevil and Pulse Beetle in Stored Sorghum and Chickpea. Karnataka Journal of Agricultural Science, 19(1), 54-57

Hasan, M., Sagheer, M., Saleem, S., Hanif, S., Akhter, S., \& Hanif, C.S.M. (2012). Evaluation of insecticidal potential of powders of Azadirachta indica, Momordica charentia and Allium sativum against Callosobruchus chinensis (Coleoptera: Bruchidae). Pakistan Entomology, 34(2), 71-73.

HDRA-the Organic Organization. 1998. The Neem Tree. www.hdra.org.uk, United Kingdom.

Hossain, S., Pittock, C., Panozzo, F., Ford, R., \& McNeil, D. (2010). Inheritance of seed size in chickpea (Cicer arietinum L.) and identification of QTL based on 100-seed weight and seed size index. African Journal of Crop Science, 4(2), 126-135.

Ileke, K. D., Bulus, D.S., \& Alaegoroye, A.Y. (2013). Effects of Three Medicinal Plant Products on Survival, Oviposition and Progeny Development of Cowpea Bruchid, Callosobruchus maculatus (Fab.) [Coleoptera: Chrysomelidae] Infesting Cowpea Seeds in Storage. Jordan Journal of Biological Science, 6(1), 61-66. http://dx.doi.org/10.12816/0000260

Kasa, A., \& Tadesse, A. (1995). Evaluation of some botanicals against the maize weevil, Sitophilus zeamais Motsch., on stored sorghum at Bako. In: Bekele E, Abdulahi A \& Yemane A, editors. Proc. 3rd annual conference of the crop protection society of Ethiopia. May 18-19, 1995, Addis Abeba, Ethiopia. Crop Protection Society of Ethiopia. pp. 120-126.

Keita, S. M., Vincent, C., Schmit, J. P., Arnason, J. T., \& Belanger, A. (2001). Efficay of essential oil of Occimum basilicum and O.gratissmum L. applied as an insecticidal fumigant and powder to control Callosobruchus maculates (Fab.) (Coleoptera: Bruchidae). Journal of $\begin{array}{llll}\text { Stored Products } & \text { Research, 339-349. }\end{array}$ http://dx.doi.org/10.1016/S0022-474X(00)00034-5

Koona, P., \& Njoya, J. (2004). Effectiveness of soyabean oil and powder from leaves of Lantana camera Linn. (Verbenaceae) as protectants of stored maize against infestation by Sitophilus zeamais Motsch. (Coleoptera: Curculionidae). Pakistan Journal of Bioscience, 7 , 2125-2129.

Malik, S.R., Saleem, M., Iqbal, U., Zahid, M.A., Bakhsh, A., \& Iqbal, S.M. (2011). Genetic analysis of physiochemical traits in chickpea (Cicer arietinum) seeds. International Journal of Agricultural Biology, 13, 1033-1036.

Menale, K., Bekele, S., Solomon, A., Tsedeke, A., Geoffrey, M., Setotaw, F., Million, E., $\&$ Kebebew, A. (2009). Current Situation and Future Outlooks of the Chickpea Sub-sector in Ethiopia. International Crops Research Institute for the Semi-Arid Tropics (ICRSAT), Nairobi \&Ethiopian Institute of Agricultural Research,,(EIAR) Deber Zeit Agricultral Research Centre, Debre Zeit, Ethiopia. 8 pp.

Pascual, N., Marco, M. P., \& Belles, X. (1990). Azadirachtin induced imaginal moult 
deficiencies in Tenebrio molitor L. (Coleoptera: Tenebrionidae). Journal of Stored Product Research, 26, 53-57. http://dx.doi.org/10.1016/0022-474X(90)90037-S

Reichert, R. D., Ooman, B. D., \& Young, C. G. (1984). Factors affecting the efficiency of abrasive type dehulling of grain legumes investigated with a new batch dehuller. Journal of Food Science and Technology, 49, 267-272.

Rigi-Assia, A.,Khelil,M.A.,Medjdoub,B.F,m \& Righi,K. (2010).Efficacy of oils and powders of some medicinal plants in biological control of the pea weevil (Callosobrchus chinensis L.). African Journal of Agricultural Research, 5, 1474-1481.

Saxena, R. C., Jilani, G., \& Abdul Kareem, A. (1989). Effects of neem on stored grain insects.. In: Jacobson M, editor. Focus on Phytochemical Pesticides. Vol. I, The Neem Tree. CRC Press, Boca Raton, FL.pp 97-111

Shaheen, F. A., Khaliq, A. (2005). Management of Pulse Beetle, Callosobruchus chinensis L. (Coleoptera: Bruchidae). Department of Entomology, University of Arid Agriculture. Rawalpindi Pakistan Entomology, 27(2), 19- 23.

Shukla, R., Srivastava, B., Kumar, R., \& Dubey, N. (2007). Potential of some Botanical Powders in reducing infestation of Chickpea by Callosobruchus chinensis L. (Coleoptera : Bruchidae). Journal of Agricultural Technology, 3, 11-19.

Singh, R. P. (1993). Neem for the management of stored grain insects in developing countries. World Neem Conf. Bangalore, India, 1993. Souvenir, pp. 69-80.

Somta, P., Talekar, N. S., \& Srinives, P. (2006). Characterization of Callosobruchus chinensis (L.) resistance in Vigna umbellata (Thunb.) Ohwi \& Ohashi. Journal of Stored Product Research, 42, 313-327. http://dx.doi.org/10.1016/j.jspr.2005.05.003

Sudheer Reddy, V., Ramesh Babu, T., \& Hussaini, S.H. (1993). Effect of inert materials on germination and grain damage by stored grain pets of sorghum. Seed Research, 1, 285-287.

Tabu, D., Selvaraj, T., Singh, S. K., \& Mulugeta, N. (2012). Management of Adzuki bean beetle (Callosobruchus chinensis L.) using some botanicals, inert materials and edible oils in stored chickpea. Journal of Agricultural Technology, 8(3), 881-902.

Tapondjou, L., Adlerb, C., Boudaa H., \& Fontemc, D. (2002). Efficacy of powder and essential oil from Chenopodium ambrosioides leaves as post-harvest grain protectants against six-stored product beetles. Journal of Stored Product Research, 38, 395-402. http://dx.doi.org/10.1016/S0022-474X(01)00044-3

Wolfson, J.L., Shade, R.E., Mentzer, P.E., \& Murdock, L.L. (1991). Efficacy of ash for controlling infestations of Callosobnichus maculatus (F.) (Coleoptera: Bruchidae) in stored cowpeas. Journal of Stored Products Research, 27, 239-243. http://dx.doi.org/10.1016/0022-474X (91) 90006-X 


\section{Copyright Disclaimer}

Copyright for this article is retained by the author(s), with first publication rights granted to the journal.

This is an open-access article distributed under the terms and conditions of the Creative Commons Attribution license (http://creativecommons.org/licenses/by/3.0/). 